T. М. Мішеніна

\title{
ЛІНГВОКОГНІТИВНА ІНТЕРПРЕТАЦІЯ ХУДОЖНЬОЇ ТВОРЧОСТІ МИТЦЯ (НА ПРИКЛАДІ ТВОРІВ ЮРІЯ МУШКЕТИКА «СТАРИЙ У ЗАДУМІ» І «СЛЬОЗА ОФЕЛІЇ»)
}

Мішеніна Т. М. Лінгвокогнітивна інтерпретація художньої творчості митця (на прикладі творів Юрія Мушкетика «Старий у задумі» і «Сльоза Офелії»).

Статтю присвячено розкриттю лінгвокогнітивних параметрів інтерпретації художньої творчості митця у доробку Юрія Мушкетика. Мистецький шлях розглянуто у співвідношенні з долею, переживання якої відбувається в рамках сакральних понять (віра, душа, дух, вічність, буття / небуття, діалектика), де душа художника переживає етапи пізнання, інтеракції, емпатії на рівні митещь / інша людина / суспільство. Поняття краси, довершеності, гармонї - через уміння відчути майстром їх зміст на рівні внутрішнього світу - душі.

Ключові слова: лінгвокогнітивна інтепретація, мовна категоризація, сакральне поняття, художній образ, естетика мистецького твору.

() Т. М. Мішеніна, 2016.

$-246-$ 
Мишенина Т. М. Лингвокогнитивная интерпретация художественного творчества творца (на примере Юрия Мушкетика «Старик в раздумье» и «Слеза Офелии»).

Статья посвящена раскрытию лингвокогнитивных параметров интерпретации художественного творчества творца в прозе Юрия Мушкетика. Путь искусства рассмотрен в соответствии с судьбой, переживание которой происходит в рамках сакральных понятий (вера, душа, дух, вечность, бытие / небытие, диалектика), где душа художника переживает этапы познания, интеракции, эмпатии на уровне твореи / другой человек / общество. Понятия красоты, совершенства, гармонии - через умение ощутить мастером содержание на уровне внутренного мира души.

Ключевые слова: лингвокогнитивная интерпретация, языковая категоризация, сакральное понятие, художественный образ, эстетика произведения искусства.

Mishenina T. M. Linguistic and cognitive interpretation of art work of an author (on the example of Yuri Mushketyk’s works «Старий у задумі» і «Сльоза Офелії»

The article is devoted to the revealing of cognitive parameters of interpretation of Yuri Mushketyk's creation. Masterful way, reproduced in Yuri Mushketyk's creation, correlates with the path of life, which is the master's fate. Since finding of the artistic image combines not only a search of the means of expression, but also hard work, writer interprets the concept of beauty, perfection, harmony through author's ability to feel their content on the level of inner world - the soul.

In the works of «Старий у задумі» і «Сльоза Офелії» a stage of the creative process, which is in observing and experiencing the events on the example of autobiographical way, interprets the content of life perception solely on brightness, sincerity, depth, on the meaningfulness of the feeling that in the creative framing is embodied in artistic image (technique (skillfulness) in the using of artistic means - vigorousness of the inner world - creativity).

Essence of the art further in Yuri Mushketyk's stories uncovers on the basis of close relationship of sensory and rational rudiments. Contemplation of the art work promotes interaction that makes possible decoding of an artistic image according to the level of aesthetic threshold and experience.

In the artistic interpretation of a work of art the figurativeness is related to the conceptual thinking on the basis of comparison, differentiation, grouping, correlation of created images pursuant to certain ideals, conceptions as the author's strictly, and those that have found consistent coverage at the level of national / world culture. The terminal component of the life in the reproducible biographical line of a sculptor correlates with socio-cultural and spiritual levels.

Author's path is largely marked with sacral thing (faith, soul, spirit, eternity, existence/ non-existence, the dialectic), where the artist's soul experiences the stages of knowledge, interactions, empathy at the level artist / other people / society.

Art reproduction combines opposites. The dialectic of the artistic image is constituted to implement the idea of correlation, which is interpreted as proportionality of soul, spirit and flesh in the religion. Artistic cost of such work is in dialectic combination of sensual (irrational) and rational (formal) with determinism of sensual vision of work. The stages of internal improvement of the sculptor realized in artistic images «Старий у задумі» i «Сльоза Офелії», «Мавка». The writer's selected genre of a parables made it possible to 
submit the philosophical and aesthetic understanding of creative way, which has a determining thing and very deep residing of existence by author's soul.

Key words: linguistic and cognitive interpretation, language categorization, sacral concept, art image, aesthetics of an artwork.

У межах мовознавчого напряму, у якому функціонування мови розглядається як різновид пізнавальної діяльності, лінгвокогнітивний аналіз уможливлює здійснення грунтовного аналізу когнітивних механізмів i структур людської свідомості через мовні явища. Когнітивна семантика сприяє виявленню й поясненню знання про світ, потрактуванню сформованих понять про світобудову, їх розкриттю на рівні концептуалізації (Ю. Апресян, Н. Арютюнова, І. Бетко, А. Вежбицька, Л. Гливінська, С. Срмоленко, В. Кононенко, В. Маслов, О. Падучева, Т. Радзієвська, М. Скаб, Г. Яворська та інші).

Розвідки науковців дозволяють переосмислити усталені позиції щодо потрактовування соціокультурних явищ, процесів, подій, абстрактних категорій.

Нашу увагу привернув творчий доробок Юрія Мушкетика, який своєрідно інтерпретує творчий процес митця, який прагне досягти досконалості своєї майстерності через внутрішнє (сакральне) переживання долі мития як інтеракції людини і вищої сили.

Новітня українська, як i європейська, література позначена морально-філософським осмисленням описуваних явищ, перевагою роздумів, своєрідної рефлексії сприйнятого i відображуваного 3 позиції діалектичного (абстрагованого) й соціокультурного (суспільно детермінованого) поглядів. Притча демонструє сюжет, у якому на передній план висувається обстоювана ідея, яка втілює сутність позиції, явища, процесу, субстанції тощо, що мають статус металогічних художніх образів. По суті йдеться про герменевтичний напрям у філософсько-естичному осмисленні художньої дійсності, який знайшов послідовну реалізацію у жанрі притчі - повчальної алегоричної оповіді, в якій фабула підпорядкована моралізаційній частині твору. На відміну від багатозначності тлумачення байки у притчі зосереджується дидактична ідея [5, с. 573]. Оригінальність авторського стилю Юрія Мушкетика визначається насамперед наочнообразною інтерпретацією дійсності, що конституюється на поняттєвому й інтуїтивно-чуттєвому вимірах в розумінні долі митця.

Мета публікації - схарактеризувати лінгвокогнітивні параметри (C) Т. М. Мішеніна, 2016. 
інтерпретації художньої творчості митця у доробку Юрія Мушкетика.

Юрій Мушкетик, художньо інтерпретуючи процес скульптуротворення як мистецтво творення малих архітектурних форм (мистецтвво - 1) творче відображення дійсності в художніх образах, творча художня діяльність // сфера творчої художньої діяльності; 2) досконале вміння в якійсь справі, галузі; майстерність [3, с. 668]; мистецтво - одна з форм суспільної свідомості, специфічний рід практично-духовного пізнання світу [8, с. 227]), оперує поняттями, що розкривають сутність творення художніми засобами (каменю):

- визнання досконалості природи і наслідування іiі як естетичний принцип творення (краса - 1) властивість, якість гарного, прекрасного; 2) оздоба, прикраса кого-, чого-небудь [3, с. 383]; гармонія - категорія, що відображає співрозмірність й упорядкованість складників цілого, єдність багатоманіття, узгодження форми і змісту об'єкта [8, с. 108]): Природа сама по собі народжує красу і гармонію, отож приймай ї̈ в душу, милуйся, вливайся в неї $(6$, с. 413);

- розуміння досконалості, довершеності мистецького твору як корелятів гармонії і краси, розуміння яких засвідчує вироблення естетичного смаку: Вона (дзвіниия Ковніра) кожного разу поставала в ньому інакше і водночас була тією ж самою, творила те ж відуття гармонії, краси, чогось схожого до міражу - щемкого, болючого, чого вічно прагне й боїться людина. Те відчуття в ньому народила й поселила назавжди дзвіниця Ковніра - мистецький твір незвичайної краси й досконалості (6, с. 356).

Мистецький твір, на думку автора, втілює вічність, визначає іï як даність, якщо ऑiі пізнає людина, осмислює, відчуває (вічність безкінечність часу існування матеріального світу, зумовлена нестворимістю і незнищенністю матерії і іï атрибутів, матеріальною єдністю світу [8, с. 87]). Підкреслимо, що кількісний аспект актуальної безкінечності полягає у відтворенні часових інтервалів, співвідносних 3 напрямами мистецтва; у якісному розумінні вічність, закладена в мистецькому витворі, охоплює послідовність якісних змін зображуваної матерії, зміну іiі станів, форм і законів руху, необмежене багатоманіття просторово-часових структур: Ноги самі несли його до дзвінищі Ковніра, де, як здавалося Долині, час переставав летіти швидко й мовби спресовувався у камені. Велике, нетлінне - в очих покладених один на один каменях, у химерних, гармонійно сплетених в одне візерунках. 
Ковнірові заміри - то вже вічність (6, с. 371); Тут скрізь позалишала свої сліди вічність. Хоч уся земля вічна, давня кожна ї̈ грудочка, нас вражають тільки ті ї̈ шматочки, де розписалася людина. Й що давніше розписалася, то глибше втискуються в мозок ті карби. «Ось цьього каменя торкнулися чиїсь руки ...» (6, с. 357).

Митець (митецьь - 1) той, хто працює в якому-небудь виді мистецтва; 2) людина, обізнана, вправна у якій-небудь справі; майстер [3, с. 668]) в аналізованих творах Юрія Мушкетика постає як людина, яка завжди перебуває в пошуку творення досконалого мистецького твору, який би максимально був наближеним до уявлення про гармонію і красу: Чеканні успіху. Кохання. A найперме - краси. Прагнення довершення... То - смуток і радість. Ми часто відчуваємо, де вона, ота довершеність, тільки не вміємо передати їі в камені чи малюнкові (6, с. 364).

У такому розумінні довершеність мистецького твору визначається мірою розуміння сутності безкінечності всесвіту протягом творчого і життєвого шляху: Суть життя $i$ особливо творення - в чеканні. Воно безконечне (6, с. 364).

У творах «Старий у задумі» і «Сльоза Офелії» етап творчого процесу, який полягає у спостереженні й переживанні подій на прикладі автобіографічного шляху, витлумачує зміст пізнання життя виключно на основі яскравості, щирості, глибини, багатозмістовності відчуття, яке у творчому обрамленні втілюється в художньому образі (техніка (вправність) у використанні художніх засобів - активність внутрішнього світу - творчість): Арсенал засобів скульптора дуже обмежений, з усіх мистецтв природа, либонь, була найскупішою до скульптора. Спробуй виразити по-справжнььому в холодному камені бодай одне почуття! Живописець тратить на те безліч кольорів, письменник добирає сотні слів, а в скульптора тільки камінь (6, с. 465); Важко, просто неможливо було віднести портрет до якоїсь школи, до якоїсь категорії. Ніби строге, класичне карбування, але водночас простота, невимушеність. 3 іншого боку - повна ясність, чистота роботи $і$ якийсь секрет, якась глибоко прихована творча нитка, яка не давалася в руки (6, с. 384).

Наведені фрагменти інтерпретують мистецтво в широкому смислі, позначаючи (поряд із високим рівня вправності, майстерності у відтворенні художніми засобами ліній, викрешуваних із кам'яної 
брили, гармонійного співвідношення ліній, досягненням естетичної значущості) насамперед специфічний духовний зміст і соціокультурне функціонування, що уможливлює втілення заданого митцем змісту в національну і світову культури.

Реалізація сформованого й осмисленого задуму потребує значних творчих зусиль, відповідної мистецької вимогливості до техніки використання художніх засобів. Автор обстоює думку про те, що талант вигартовується значною мірою тривалою, часто важкою працею, позначеною численними невдалими спробами. Технічні грані таланту митця набувають вивершеності за умови поєднання вправності у техніці, безперервності зусиль і глибини почуття (працелюбність - властивість за значенням працелюбний (який любить працю, старанно, ревно, із запалом працює) [3, с. 1103]): Це було мовби німе змагання. Сашко тесав і тесав. I все - майже безуспішно. Й тоді він відважився вдруге. На оцюю мармурову брилу. Він зумів зберегти віру, щчоденно гартував ї̈, споглядаючи отой вже обтесаний, безживний мармур. Він змушував себе ходити до дзвіниці Ковніра, дивитися на товсті столітні мури й контрфорси. Контрфорси стояли, а віра почала ламатися (6, с. 361).

Творчий процес у розглядуваних творах розгортається через визначальний внутрішній складник (віра - у гносеології і методології науки прийняття будь-якого знання без безпосереднього емпірійного й раціонального обгрунтувань [8, с. 85]; натхнення - стан людини, що характеризується піднесенням iї творчих сил, активізацією всіх психічних процесів [3, с. 741]): Різав камінь і почував невситиму жсагу, яку не можна було погамувати. Так, це було більше, ніж просте бажання працювати. Він бачив, як точно лягає удар різця, як ...байдуже обличчя (скульптури) перетворюється на тонке, сповнене задуми обличчя невідомої людини. Він не міг пояснити, з чого йшли ия віра і натхнення (с. 369). У наведеному контексті розуміємо жагу як творчу енергію, що дозволяє трансформувати від чуттєві параметри у художньому образі, що певною мірою наближається до енергії суті всесвіту (енергія - 1. Одна з основних властивостей матерії, загальна міра всіх форм руху [3, с. 351$])$.

Оскільки розуміння віри й натхнення стягується під один знаменник світовідчуття душею (душа - 1) внутрішній психічний світ людини з їі настроями, переживаннями та почуттями // за релігійними 
уявленнями - безсмертна нематеріальна основа в людині, що становить суть іiі життя, є джерелом психічних явищ і відрізняє іiі від тварини; 2) сукупність рис, якостей, властивих певній особі // людина як носій тих чи тих рис, якостей; // почуття, натхнення, енергія // про людину з прекрасними рисами характеру [3, с. 333]), констатуємо перевагу чуттєвого складника, що сприяє якомога повному відтворенню пізнаного процесу, явища; пережитого конструктивного / деструктивного стану. Маємо говорити про первинність душевної рівноваги, що уможливлює створення довершеного мистецького твору: I ще більше дивувався, щзо йому все дужче $i$ дужче починає подобатись оця невідома людина, він мовби витягав ї̈ з небуття, вів у життя, наближав до себе, входив з нею у якісь тонкі, що химерно переплелися в його душі стосунки (6, с. 369) - буття / небуття художнього образу. У наведеному текстовому фрагменті семантичний простір лексеми душа охоплює компоненти відчуття, буття.

Сутність мистецтва далі у повістях Юрія Мушкетика розкривається на основі тісного взаємозв'язку чуттєвого й раціонального начал. Споглядання мистецького твору сприяє інтеракції, що уможливлює декодування художнього образу відповідно до рівня естетичного порогу та життєвого досвіду. Критерієм довершеності мистецького твору визначається його душевно трансформаційного, емпатійного потенціалу: Тверезо $i$ розважливо подумав, щзо мав би ... втішатися Дніпром, п'янким вітром, високим небом. Щоб вони вливалися в нього, сповнювали снагою $і$ енергією. Але він не вмів того. Просто не міг жити так, плинути кудись з рікою, з літом і не думати, куди плине. Він усе осягав розумом. Тільки розумом. Його стихісю, його жнттям стало мистецтво, хоч $i$ в ньому, почував, теж жив занадто тверезо. А воно (мистецтво - Т.М.) - порив, шилений біг крові і солодка туга в серці. Адже тільки така туга може народити відгомін в іншому серці, $і$ це серце все зрозуміс й собі заплаче або засміється. I тоді возвеличить розумом їхнього творця. Отого мития, щуо виплеснув їх y світ. А він того не вмів (6, с. 401). Розмежовуємо поняття душа (почуття) і дуx (розум) (дуx - мислення, свідомість, позамисленнєві аспекти: воля, уява, інтуїція тощо [8, с. 185]): те, що відчуте душею, вистраждане може відтворити розум 3 допомогою художніх засобів.

Інтеракція уможливлює герменевтичне розуміння значеннєвих

(C) Т. М. Мішеніна, 2016. 
відтінків художнього образу: ... Його (скульптора) піймало почуття, буцім і справді зустрівся з кимось знайомим, із ким не сподівався $і$ не хотів зустрітись. Оия тиша, очя напівтемрява творили настрій невидимого спілкування, обопільного споглядання (6, с. 407).

Становлення справжнього майстра спостерігаємо відповідно до етапів вироблення душевного поступу, що має реалізацію відчуття внутрішнього світу:

- окремої людини: «Лісову пісню» Долина знав трохи не напам'ять. Але тепер ия драма наповнилася для нього новим змістом. I той зміст принесла Люся. ... Мабуть, то була трагедія самої Люсі... Вся наструнчена, тонка й чутлива, мов скрипка... (6, с. 426);

- усталених стандартів відображення внутрішніх станів i почуттів; осмислених етапів життєвого шляху: ... Він (скульптор) уже інтуїтивно вловлював мистецьку суть кохання, його найтрахічнішу ноту, котрої ще нікому не вдалося виразити. Відмовся від кохання - ие майже смерть, заперечення буття, але ж хіба може серце, коли б’ється, заперечити себе? Хіба воно не поривається, хіба не хоче продовжитись у світі? I ия суть захована не тільки в згасанні кохання. А й усього сущьог. Хіба наше жсиття не є одним з виявів цього закону? (6, с. 427); ... Він не уклав своєї концепції образу, а тільки вловив висловлену геніальною поетесою мить людського болю й надлому, трагічність відходження в небуття того, щи породжене буттям (6, с. 431);

- власне переживання подібних станів і почуттів, перевага чуттєвого (ірраціонального) над осмисленням раціонального створення художнього образу: Ті слова: «Я хочу забуття!» - були сповнені справжнього, а не артистичного болю і справжньої розпуки. Вони призначались... Він (скульптор) тільки почував у серці жсивий біль втрати $і$ потребу та силу зупинити його, відтворити в камені. Відтворити саме оте, повернене назад, щзо залишала Мавка, щзо призначалося саме йому. Так, воно було його, тільки його, $і$ через те $в$ його серці й виникло бажання викарбувати його в камені. Він його викарбує. ... Але люди відчують силу його почуття, його мистецьку силу (6, с. 428);

- усвідомлення того, що лише власний пережитий досвід радостей і болів, розуміння внутрішнього стану іншого (емпатія) уможливлюють мистецьке утілення в художньому образі досвіду 
людства (мистещуьке прозріння - мистецька вправність): ... Він повірив, щу йому вдалося вчинити майже мефістофельський обмін: взамін любові одержати мистецьке прозріння, $i$ він був готовий погодитися на те (6, с. 431); Насамперед він почав порівнювати ї̈ (Мавку) з тим, щзо задумував спочатку, щзо намагався вдихнути в оцю холодну глину. Він хотів владі мороку, яка уже, по суті, забрала людину, протиставити інстинктивний порив до жсття, до світла, до любові: Мавка йде в небуття не тому, щзо Марище дужче, а щзо в неї самої не вистачило більше сили жити, страждати й мучитись $i$ щось у ній шкодує за тим. Чорну силу він не збирався зображувати вона мала мовби повиснути над скульптурою, тобто ї повинні вгадувати, а момент боротьби мав закарбувати вочевидь (6, с. 436).

Художнє мислення як синтезований психічний процес, що передує створенню мистецького твору, об'єднує уявлення й образи уяви, почуття (відчуття), які через численність i глибину уможливлюють створення чуттєво-конкретного образу, який одночасно є інтенційним, тобто передбачає додаткові значеннєві відтінки, змістове навантаження яких залежить як від порогу естетичної чутливості того, хто сприймає й декодує мистецький твір, так і від досвіду переживання реальних подій на різних етапах життєвого шляху та чуттєвого досвіду їх переживання.

Ідеться про так званий шлях особистості, який становить не лише природно-історичний процес, що повторюється, але й унікальний сценарій життя як своєрідної драми, кожна сцена якої $є$ результатом поєднання i подальшого перебігу індивідуальнонеповторних характерів і обставин [4, с. 67-69]. Осмислення життєвого шляху поєднує біограрафічне й історичне, що знаходить послідовне відображення в історії формування й подальшого розвитку людини в певній соціокультурній дійсності, сучасника доби, й ровесника певного покоління [1, с. 104-105]. Оскільки 3 вище зазначеного життєвий шлях митця є одночасно індивідуальним й суспільно-історичним, життєвий світ митця вибудовується у процесі саморозгортання особистості, зростання його суб'єктності й подальшої автономності в осмисленні подій, що відбуваються, здатності до рефлексії того, що відбувається. У такий спосіб подійнобіографічний вектор художнього відтворення конкретно-чуттєвих образів дозволяє втілити образ «життєвого шляху митця» в контексті

() Т. М. Мішеніна, 2016. 
всього суспільства (минулого, особливостей культурного розвою; умов, які створюються в соціокультурній дійсності задля розвитку особистості, можливостей утілення їі перспектив, планів, сподівань і можливих умов та засобів їх досягнення).

У художній інтерпретації мистецького твору образність співвідноситься 3 понятійним мисленням на грунті зіставлення, диференціації, групування, взаємозв'язку створюваних образів відповідно до певних ідеалів, концепцій як власне митця, так і тих, що знайшли послідовне висвітлення на рівні національної / світової культури.

Особливістю зіставлення в художній творчості Юрія Мушкетика є наскрізне порівняння образів, утілених у скульптурі, 3 літературними образами національної культури (Мавки); світової культури (Офелії).

Загальновідомим $\epsilon$ те, що митець художніми засобами відтворює у його змісті духовні цінності (добро, краса, любов, жертовність, справедливість, сміливість, звитяга, патріотизм, чесність, істина, щуиість, духовність, иляхетність тощо), інтеріоризація (засвоєння) яких сприяє подальшому одухотворенню людини, сприяє розкриттю окремої особистості й суспільства в цілому розвиватися відповідно до заданих ідеалів краси й істини.

Скульптурні портрети Мавки й Офелї̈, відтворювані засобами типізації літературних героїв, становлять символи сконденсованого життєвого досвіду, які реалізуються в досвіді переживання митцем любові і зради; життя і смерті; духовного піднесення і його занепаду (або уповільнення). Елементи мистецької майстерності скульптора, які сприяють винюансовуванню стилістичної вправності, побудовані на основі поєднання викрешуваних ліній і вправності наслідування реальний прообразів, становлять їх художньо-естетичну вартість.

Термінальний складник життя у відтворюваній подійнобіографічній лінії скульптора співвідноситься із соціокультурним і духовним рівнями.

Критерієм довершеності мистецького твору вплив на душу людини, ушляхетнення iіi, спрямування iї до цінностей суспільства: ... Митці покликані творити красу, оточувати нею людину, будити в ї̈ душі високе й притлумлювати низьке. Тільки вдосконалюючи душу власну і тих, хто живе поруч з тобою, є смисл летіти разом з цією 
зеленою кулькою довкола он того вогняного кружала (6, с. 356). Наведений уривок переконує в тому, що лексема душа становить не лише (i не стільки) лінгвостилістичний елемент, а набуває символічного значення - душа як сутність (духовна основа людини), причому означальний складник духовний співвідносний iз внутрішньою формою аналізованого поняття 3 позиції первинного тлумачення сутності людини в релігійному ракурсі (людина є душею). Убачаємо також потужний виховний потенціал мистецького твору, оскільки він здатен удосконалювати дущу, яка потребує уваги, любові до себе і має безперервно розвиватися.

Діалектичний взаємозв'язок убачаємо в тому, що такого зразка мистецький твір може мати місце, якщо сам його творець має такі цінності інтеріоризованими i такими, які набули значущості на прикладі власного життєвого шляху. Юрій Мушкетик послідовно доводить думку про те, що илях митця $\epsilon$ його долею, тобто сукупністю каузально-причинових подій, які водночас мають основним складником досвід його душі: B світі $\epsilon$ речі, які може осягнути тільки досвід. В кінцевому результаті талант, мабуть, ие теж тільки досвід, сконцентрований у якійсь краплині і переданий чи то ранковим променем, чи співом солов'я, чи співом матері, чи порухом батькової руки. А потім талант примножус досвід (6, с. 389) - талант - видатні природні здібності людини; хист, обдаровання // здібності до чогось, уміння робити щось [3, с. 1428]; хист - уміння що-небудь робити; здібності // надзвичайний природний дар, високий ступінь обдарованості, талант. Природний нахил, потяг до чого-небудь [3, с. 1561]. Наведений уривок дозволяе говорити про використання лексеми досвід для позначення психічного світу певного колективу людей, нації (ідеться про ментальність як динамічну структуру, що розкриває національно-психологічні особливості національної психології; особливості світорозуміння). Національною специфікою української культури, яка визначає органічну рису мистецьких творів, є світосприйняття через усталені образи ранкового променя, співу солов'я, співу матері, поруху батькової руки.

Набутий досвід митець утілює в художньому образі, який відображає неповторність пройденого життєвого шляху. Його глибоке внутрішнє переосмислення: Те, що здобувається ціною власної крові, серця - його не вимірясш ніякою міркою. Бо немає однієї мірки 
навіть для двох людей. Так, ие цінності, які не мають одного еталона, в кожному окремому випадку - окрема міра... Узгодження 3 совістю - то не проста річ (6, с. 421). Совість розуміється як камертон душі: лише справжні відчуття, переживання можуть надати художньому образові глибини, відтворити зміст гармонії; мистецька імітація відчуттів залишить художній образ нерухливим, не здатним на інтеракцію з внутрішнім світом іншої людини.

Утілення досвіду переживання своєї долі діалектично поєднує радості і страждання; такий досвід сприяє виробленню високості душі, що, на думку автора, і становить критерій мистецької вартості твору уміння передати напругу i безмір внутрішнього життя людини, переживань і почуттів, які становлять основу людського єства: ... Влізти у камінь. Заціпеніти в мармурі. Скільки зможеш, теши себе самого. В іншій оболонці. Вдосконалюй свос сство. Нехай душа відіб’ється задумою на обличчі. Не бійся, скінчиш, вилізеш, хоч частка душі й залишиться там. Але саме вона й промовлятиме до всіх... (6, с. 367); У справжньвому творі видно глибину душі того, хто творить (6, с. 465); Вона (дзвіниця Ковніра) стояла на крутій горі по той бік байраку, вся залита призахідним сонщем, стрімкі бокові шпилі й округла баня, витонченість і простота, якесь дивне чарівне поєднання природного смаку, розрахунку, мрійливої задуми $i$ буряного пориву стражденної душі (6, с. 356).

Розуміння долі як перебігу подій, їх глибоке осмислення, усвідомлення їх умотивованості, що уможливлює якісну зміну внутрішнього психічного світу людини, актуалізує додатковий семантичний відтінок осмислення, рефлексії, задуми. Такий погляд на життєвий шлях актуалізує перевагу в людині іiі сакрального внутрішнього світу: Він уже давно бачив, щзо його скульптурний портрет - щзось більше, ніж просто «Старий у задумі». Що ие не буденна задума, а задума над долею. Над тим, щзо збулося й щзо не збулося. Старий занурився в думу глибоко, до краю (6, с. 381).

Подамо коментар про те, що доля у повістях Юрія Мушкетика потрактовується, на наше переконання, відповідно до християнського бачення світобудови, пор.: доля - перебіг подій, збіг обставин, напрям життєвого шляху, що ніби залежать від бажання, волі людини; // умови життя; життєвий шлях і те, що на ньому трапляється [3, с. 315]; доля - визначеність подій і вчинків людини; каузальна детермінація 
[8, с. 635]. Повість-притча «Старий у задумі» і повість «Сльоза Офелії» розгортає життєвий шлях митця, побудований на глибокому співрозуміння вищої сили i митця, який прагне відтворити досконалість через чуттєву тотожність. Іншими словами, поняття долі митця не стільки передбачена, скільки спрямована на звершення; така, що надає змогу митцю реалізувати енергійну творчу якість, якою його налічено (активізовано такі додаткові семантичні компоненти: визначеність, достатність, иілеспрямованість, віра, доленосність).

Зважаючи на те, що мистецький твір має перевагою духовний початок, його художнє відтворення співмірно поєднує протилежності, діалектика художнього образу конституюється на реалізації ідеї взаємозв'язку, що витлумачується в релігії як співмірність душі, духу $i$ nлоті. Художня вартість такого твору полягає в діалектиці поєднання чуттєвого (ірраціонального) й раціонального (формального) 3 детермінованістю чуттєвого бачення твору (діалектика - загальний взаємозв'язок, становлення і розвиток, які осмислюються з допомогою усієї історично сформованої системи категорій і законів [8, с. 163]). Діалектика поєднання ідеального й матеріального уможливлює рух душі, їі розвиток у:

- щасті і горі; злетах і занепадах; радостях і печалях; русі i спокої в долі (на життєвому шляху): Задума мусить бути красивою... Скульптор відчув якийсь новий, ще один сенс своєї роботи, і йому здалося, що відгадав, чого не вистачає його скульптурі. Внутрішньої иляхетності, високості мислі. Отже, його старий думас хоч і гірко, але шляхетно й високо. Він здатний на суворе, а може, й фатальне рішення, - вистраждав його, виболів у тяжкій задумі, - але він не здатен на підлоту (6, с. 383);

- житті і смерті; коханні і стражданні від нерозділеного кохання (втраченого кохання): Мавка... 3 боку мистецької техніки... Це мало бути протиставлення руху й спокою. В оцьому спокої мав жити порив оживлення мармуру (6, с. 436); $B$ «Офелї̈» поєдналися, злилися 8 одне дві сили: сила стражнданя і сила кохання. Й обидві такі бездонні, що стискається серие. Кохання не може бути вічне, воно минуще (кохання вгадується в скульптурі, хоч, здається, скульптор $i$ «не планував» його), а страждання може бути безкінечним, бо воно вічне, й безмір страждання закарбувався на обличчі дівчини. Це могло бути будь-яке страждання - не лиме любові, кривди, неправди, 
власної недосконалості, зневіри в близьких і рідних $i$ самому світові. Можна було сказати, щуо цее мука душі, духу, а не плоті, плоть болить, а дух - стражәас (6, с. 464).

Найвищим рівнем вияву майстерності митця $\epsilon$ уміння «оживити» матеріал, який здатен утілити / імітувати момент поруху душі людини. У цьому і полягає справжня діалектика досконалого художнього образу: ... Справжня творчість складна. ... Талант вбирає у себе все - всі думки, переживання, устремління багатьох людей свого покоління. А тут мовби немає й складності. Все просто... А осягти до кінцяя неможливо. Горе каменю значно більше за будь-яке твоє, пережите раніше. Й иим воно тривожить, ичим непокоїть: не тільки тією простою сентенцією, що на землі є дві крайні точки -радості й страждання, а щзо точки цүі до кінця щзе не осягнені людиною, людство до них ще не дійшло. ... Потаємний смисл "Офелї̈ - у засторозі (6, с. 464); Глибокі зморшки, які скульптор проклав на чолі і щоках старого, надавали портрету повної схожості з обличчям старої людини, а кілька менших, ледь помітних, підкреслювали й інше - невпинну руйнацію, швидкий поступ людини в небуття... Скульптору здавалося, щуо обіймає світ ширше, плин ніше, діалектніше. Так, пролягають глибокі борозни, але очі не сумують за тим і думка не гасне, вона знає: десь народжуються нові пластичні лінії, новий неспинний рух (6, с. 381).

Первинність душевного прозріння передбачає зануреність душі людини-митця у створювану / модельовану художню дійсність, глибинне переживання на рівні інша людина - митець - нащія людство (шедевр - зразковий витвір, що є найвищим досягненням мистецтва, майстерності [3, с. 1617]): Шедеври з'являються рідко. Здебільшого вони забирають всю людськудушу (6, с. 492).

Мистецький шлях, відтворений у доробку Юрія Мушкетика, співвідноситься із життєвим шляхом, який є долею мития. Оскільки віднайдення художнього образу поєднує не лише пошук виражальних засобів, але і наполегливу працю, прозаїк інтерпретує поняття краси, довершеності, гармонї через уміння відчути майстром їх зміст на рівні внутрішнього світу - душі. Мистецький шлях позначений значною мірою сакральністю (віра, душа, дух, вічність, буття / небуття, діалектика), де душа художника переживає етапи пізнання, інтеракції, емпатії на рівні митецьь / інша людина / суспільство. Етапи 
внутрішнього вдосконалення скульптора відтворені у художніх образах «Старого у задумі», «Мавки», «Сльоза Офелії». Обраний письменником жанр притчі дозволив подати філософсько-естетичне розуміння творчого шляху, ознакою якого $\epsilon$ доленосність i надзвичайно глибоке проживання буття душею митця.

\section{Література}

1. Ананьев Б. Г. Человек как предмет познания / Б. Г. Ананьев. - Л. : ЛГУ, 1968. $340 \mathrm{c}$.

2. Арютюнова Н. Д. Язык и мир человека / Н. Д. Арютюнова. - [2-е изд., испр.]. М. : Языки русской культуры, 1999. - 896 с.

3. Великий тлумачний словник сучасної української мови / [уклад. і голов. ред. В.Т. Бусел]. - К. - Ірпінь : ВТФ «Перун», 2007. - 1736 с.

4. Кроник А. А. Новые методы психологии жизненного пути / А. А. Кроник. М. : Наука, 1993. - 280 с.

5. Літературознавчий словник-довідник / [Р. Т. Гром'як, Ю. І. Ковалів та ін.]. К. : ВЦ «Академія», 1997. - 752 с.

6. Мушкетик Ю. М. Твори : у 5 т. Т. 4. : Біль: повість; Обвал : повість; «Старий у задумі» : повість-притча; «Сльоза Офелії» : повість / Ю. М. Мушкетик. - К. : Дніпро, 1988. - $493 \mathrm{c}$.

7. Скаб М. В. Закономірності концептуалізації та мовної категоризації сакральної сфери / М. В. Скаб. - Чернівці : Рута, 2008. - 560 с.

8. Философский энциклопедический словарь / [редкол. : С. С. Аверинцев, Э. А. АрабОглы, Л. Ф. Ильичев и др.]. - [2-е изд.]. - М. : Сов. Энциклопедия, 1989. - 815 с.

9. Юркевич П. Д. Сердце и его значение в духовной жизни человека, по учению слова Божия / П. Д. Юркевич // Философские произведения. - М. : Правда, 1990. C. $69-104$.

10. Яковлев Е. Г. Художник: личность и творчество / Е. Г. Яковлев // Эстетика : [учебное пособие]. - М. : Гардарики, 2004. - С. 132-283.

Стаття надійшла до редакиї 29.11.2015 p. 